\title{
Project-Based Drawing Activities in Improving Social-Emotional Skills of Early Childhood
}

\author{
Christiani Endah Poerwati $^{1}$, I Made Elia Cahaya ${ }^{2}$ \\ Program Studi PG- PAUD, Fakultas Ekonomika dan Humaniora, \\ Universitas Dhyana Pura, Bali, Indonesia
}

\begin{abstract}
This study aims to improve children's social-emotional abilities through project-based drawing activities. The study was conducted on children of PAUD Pelita Kasih, Dalung group B semester 2 academic year 2017/2018. This type of research is action research with a fourstage procedure, namely: 1) Planning phase, 2) Action taking phase, 3) Development phase, 4) Reflection phase. The research was carried out in two cycles. Data collection methods used in this study are through observation. The process of collecting data through this observation technique uses a rubric guide to record data about the social-emotional abilities shown by early childhood in project-based drawing activities. The results of the study showed an increase in children's social-emotional abilities in project-based drawing activities. Completeness of children's social-emotional abilities in the initial observation of 17 children (68\%), the cycle I as many as 19 children (76\%), and cycle II 23 children (92\%). So it can be said that the project method as an alternative method of learning that is creative, innovative and effective in drawing activities that can improve the social-emotional abilities of early childhood.
\end{abstract}

Keywords: Early Childhood, Drawing Activities, Project Methods, Social Emotional Abilities

\begin{abstract}
Abstrak
Penelitian ini bertujuan untuk meningkatkan kemampuan sosial-emosional anak melalui kegiatan menggambar berbasis proyek. Penelitian dilaksanakan pada anak PAUD Pelita Kasih, Dalung kelompok B semester 2 tahun pelajaran 2017/2018. Jenis penelitian ini adalah penelitian tindakan (action research) dengan prosedur empat-tahap, yaitu: 1) Tahap perencanaan, 2) Tahap pengambilan tindakan, 3) Tahap pengembangan, 4) Tahap refleksi. Penelitian dilaksanakan dalam dua siklus. Metode pengumpulan data yang digunakan dalam penelitian ini yakni melalui observasi. Proses pengumpulan data melalui teknik observasi ini menggunakan panduan rubrik untuk merekam data mengenai kemampuan sosial-emosional yang ditunjukkan anak usia dini dalam kegiatan menggambar berbasis proyek. Hasil penelitian menunjukkan peningkatan kemampuan sosial-emosional anak dalam kegiatan menggambar berbasis proyek. Ketuntasan kemampuan sosial emosional anak pada observasi awal 17 anak (68\%), siklus I sebanyak 19 anak (76\%), dan siklus II 23 anak (92\%). Maka dapat dikatakan bahwa metode proyek sebagai salah satu alternatif metode pembelajaran yang kreatif, inovatif dan efektif dalam kegiatan menggambar yang dapat meningkatkan kemampuan sosialemosional anak usia dini.
\end{abstract}

Kata Kunci: Anak Usia Dini, Kegiatan Menggambar, Metode Proyek, Kemampuan sosial emosional

@Jurnal Obsesi Prodi PG-PAUD FIP UPTT 2018

$\triangle$ Corresponding author :

Address : Denpasar Bali

Email : christianiendah@undhirabali.ac.id 


\section{PENDAHULUAN}

Anak Usia Dini (0-6 tahun) sejatinya memiliki berbagai potensi bawaan yang harus ditumbuhkembangkan menjadi kemampuan yang aktual melalui stimulasi yang tepat. Pendidikan Anak Usia Dini (PAUD) merupakan pendidikan prasekolah bagi anak usia dini yang mengemban tugas menyediakan dan memfasilitasi berbagai stimulasi tumbuh kembang anak agar mencapai perkembangan yang optimal, baik fisik maupun mentalnya. PAUD merupakan peletakan dasar enam dasar perkembangan anak yang meliputi perkembangan agama dan moral, fisik-motorik, bahasa, kognitif, sosial-emosional, dan seni sebagaimana tercanttum dalam Permendikbud No 146 Tahun 2014 (Kemendikbud, 2014). Pembelajaran akademis yang efektif sangat penting; namun, mengajarkan keterampilan sosial sama pentingnya karena kinerja anak di sekolah berkaitan dengan kemampuan mereka dalam bergaul dengan teman sebaya dan orang dewasa dan mengikuti peraturan di lingkungan anak. Anak yang menunjukkan keterampilan sosial yang buruk cenderung ditolak oleh orang lain dan sering dihukum karena ketidakmampuan mereka untuk mematuhi kebijakan dan prosedur sekolah (Lovitt, 2007). Perkembangan sosial anak yang sehat bergantung pada pembelajaran dan standar internalisasi perilaku sosial serta dalam mentransfer dan menerapkan standar ini dalam berperilaku anak di berbagai lingkungan dan situasi. Kompetensi sosial terkait dengan penerimaan teman sebaya, penerimaan guru, dan keberhasilan pasca sekolah. Selain keluarga, sekolah memberikan pengaruh yang dominan dalam kehidupan anak-anak saat mereka berkembang secara sosial dan emosional (Cartledge, G., \& Kiarie, 2011).

Keterampilan sosial merupakan kebutuhan mendasar anak agar mampu berinteraksi dan menghadapi berbagai situasi yang terjadi disekitarnya, sedangkan kemampuan mengekspresikan emosi secara tepat terhadap perasaan sendiri mapun orang lain meningkatkan kepercayaan diri anak dalam menghadapi berbagai situasi. Pendidikan prasekolah merupakan saat yang tepat dalam mendidik dan membina kemampuan ini melalui berbagai kegiatan, yaitu kegiatan yang menuntun anak bekerja dalam sebuah kelompok. Menggambar merupakan kegiatan individual di mana anak menuangkan ide dan imajinasi serta kemampuan seni dan kreativitasnya, namun kegiatan ini dapat dikembangkan menjadi kegiatan kelompok tanpa meninggalkan individualitas anak. Kegiatan menggambar merupakan kegiatan yang menyenangkan bagi anak, karena melalui menggambar anak dapat mengungkapkan perasaannya terhadap pengalaman, kejadian, bercerita, gagasan abstraknya, bahkan berinteraksi dengan teman sebaya.

Kegiatan menggambar yang di rancang sebagai kegiatan kelompok melalui pembuatan poster dan buku cerita akan mampu mengembangkan keterampilan sosial anak dalam situasi kelompok. Masing-masing anak mengembangkan ide dan kreativitas seni melalui kegiatan menggambar sebagai hasil diskusi dan kesepakatan kelompok. Hasil gambar setiap anak digabung dalam bentuk sebuah karya poster dan buku cerita sebagai satu kesatuan karya kelompok. Setiap karya dipresentasikan sebagai hasil bentuk kerjasama yang utuh menyatu dalam keberagaman, namun tetap menghargai individualitas.

Penelitian (Günindi, 2015) menunjukkan bahwa gambar yang dihasilkan oleh anak-anak dapat digunakan untuk menilai pendapat dan persepsi anak, penyebab masalah terkait nilai yang anak hadapi di lingkungan sekolah dan keluarga, dan solusi yang anak pikirkan dalam memecahkan masalah ini. Kaitannya dengan 'kasih sayang' dalam penelitian ini, data yang diperoleh sangat berharga karena bagi peneliti tidak ada penelitian yang ada mengenai persepsi anak tentang nilai 'kasih sayang' dengan menggunakan gambar. Berdasarkan penelitian di atas dapat dinyatakan bahwa melalui gambar anak dapat mengekspresikan pikiran dan perasaannya, bahkan masalah yang dihadapi anak. 
Kegiatan menggambar berbasis proyek dapat melatih anak untuk berinteraksi dalam kelompok, menghadapi perbedaan, menghargai pendapat orang lain, kerjasama, memecahkan masalah, toleran, pengendalian diri, percaya diri sekaligus menunjukkan kemampuan diri.

Pertumbuhan sosial emosional merujuk pada dua jenis pertumbuhan. Pertumbuhan emosional adalah pertumbuhan perasaan anak, dan pertumbuhan sosial adalah pertumbuhan anak sebagai anggota kelompok. Perkembangan emosi dan sosial adalah proses berkembangnya kemampuan anak untuk menyesuaikan diri terhadap dunia sosial yang lebih luas (Soetjiningsih, 2012). Belajar menjadi anggota dari sebuah kelompok melibatkan banyak keterampilan sosial. anak-anak, misalnya, harus belajar untuk berhubungan dengan anak-anak lain dan orang dewasa di luar keluarga. Seringkali, pengalaman pertama anak berbagi perhatian orang dewasa dengan anak-anak lain terjadi dalam suatu situasi. Keterampilan sosial melibatkan anak untuk belajar bekerja dalam kelompok, belajar bagaimana berbagi, bergiliran, mendengarkan orang lain, dan bagaimana dan kapan bekerja sendiri.

Pada masa ini, anak menjadi lebih peka terhadap perasaannya sendiri dan perasaan orang lain. Mereka dapat lebih baik mengatur ekspresi emosionalnya dalam situasi sosial dan mereka dapat merespons tekanan emosional orang lain. Secara bertahap anak juga dapat memverbalisasi emosi yang saling bertentangan. Selain itu anak juga mulai dapat melakukan kontrol terhadap emosi negatif. Anak-anak belajar tentang apa yang membuat mereka marah, sedih, atau takut, serta bagaimana orang lain bereaksi dalam menunjukkan emosi ini dan mereka belajar mengadaptasikan perilaku mereka dengan emosi-emosi tersebut (Papalia, Diane E. Sally Wendkos Old, 2010).

Emosi (kadang-kadang disebut sebagai perilaku) adalah perasaan, baik fisiologis dan psikologis dalam menanggapi peristiwa pribadi yang relevan dengan kebutuhan dan tujuan anak. Anak-anak bertumbuh, rentang emosi mereka semakin luas, anak juga semakin menyadari perasaan mereka sendiri dan orang lain (Papalia, Diane E. Sally Wendkos Old, 2010). Umumnya ungkapan emosi merupakan ungkapan yang menyenangkan. Anak-anak suka tertawa genit atau tertawa terbahak-bahak, menggeliat, mengejangkan tubuh, atau berguling-guling di lantai, dan pada umumnya menunjukkan pelepasan dorongan-dorongan yang tertahan. Untuk standar orang dewasa ungkapan emosional ini kurang matang, tetapi pada anak hal ini menandakan bahwa anak berbahagia dan anak mempunyai penyesuaian diri yang baik (Hurlock, 2012).

Walaupun dapat menimbulkan akibat yang tidak baik, namun keanggotaan kelompok merupakan hal yang penting bagi anak dalam rangka membantu proses sosialisasi seperti : Belajar bekerja sama serta berperilaku sosial. Bersaing dengan orang lain dengan sikap sportif mau menerima dan melaksanakan tanggung jawab serta mampu menyasuaikan diri dan tidak tergantung pada orang lain (Soetjiningsih, 2012).

Sebagai makhluk sosial anak memerlukan lingkungan untuk berinteraksi dan bersosialisasi dengan mengembangkan potensi berkomunikasi verbal dan non verbal dalam menyatakan perasaan, sikap dan pikirannya. Proses interaksi ini akan menumbuhkan kepercayaan diri dan penerimaan diri anak terhadap diri sendiri dan orang lain.

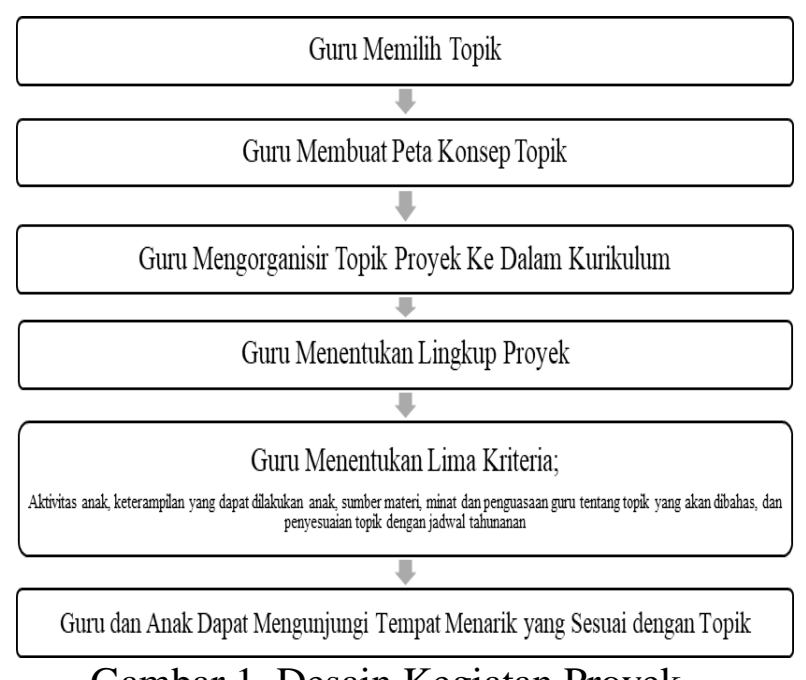

Gambar 1. Desain Kegiatan Proyek

(Sumber: (Rachmawati, 2010) 
186 | Project-Based Drawing Activities in Improving Social-Emotional Skills of Early Childhood

Gambar adalah sebuah permainan, selama itu tidak memaksa, justru seharusnya dapat menghibur si pembuatnya. Selain itu gambar mengungkapkan banyak kenyataan dalam kehidupan. Gambar adalah sebuah mimpi di atas kertas, di mana muncul keinginankeinginan, baik disadari maupun tidak. Gambar adalah sebuah kenyataan dari pikiran-pikiran anak, pada momen tertentu, mendorongnya untuk menggambar. Gambar juga merupakan sebuah hadiah berharga yang diberikan anak kepada orang-orang yang disayanginya (Davido, 2012), Material yang dibutuhkan untuk menggambar :

1. Selembar kertas putih dan berwarna dengan berbagai ukuran

2. Pensil

3. Pena warna

4. Pastel

5. Krayon

6. Pena fluoresen (highlighter) dengan warna-warna cerah

Anak prasekolah cenderung lebih suka menggunakan ukuran kertas yang lebih lebar. Meskipun umumnya anak suka menggunakan kertas putih, lembar kertas berwarna kadang-kadang menarik minat anak, khususnya yang kurang percaya dengan kemampuan menggambarnya. Sebaiknya tidak menyediakan penghapus, sebagai gantinya dorong anak untuk mencoba lagi bila anak tidak puas dengan gambarnya (Geldard, 2012).

hal :

Gambar bermanfaat untuk berbagai

1. Untuk menguji kematangan pikiran. Dari sebuah gambar, tingkat kecerdasan seorang anak (intellectual quotient) dapat diukur.

2. Untuk media komunikasi. Gambar dapat memperbaiki kekurangan yang mungkin ada pada kemahiran berbahasa anak. Dengan gambar dapat dijelaskan apa yang dialami atau dirasakan anak, yang mungkin tidak dapat dijelaskan melalui tulisan.

3. Untuk mengeksplorasi perasaan anak

4. Untuk pengetahuan tentang tubuh dan lingkungan sekitarnya (Davido, 2012).
Tujuan menggambar mencakup :

1. Membuat anak dapat menuturkan ceritanya.

2. Membuat anak mengekspresikan perasaan emosional yang terpendam atau dalam

3. Membantu anak mendapatkan rasa menguasai peristiwa yang sudah atau sedang mereka alami (Geldard, 2012).

Kegiatan menggambar berbasis proyek yang dimaksud dalam penelitian ini adalah kegiatan menggambar yang dikerjakan secara individu namun menghasilkan karya kelompok.

1. Membuat poster. Anak menggambar sebuah poster pada sebuah kertas besar secara berkelompok, dengan membagi tugas setiap anggota. Gambar yang dihasilkan sesuai dengan tema yang disepakati.

2. Membuat buku cerita. Setiap anak menggambar pada selembar kertas secara individu. Hasil setiap gambar anak disatukan menjadi sebuah buku cerita. Secara berkelompok anak mendiskusikan alur cerita sesuai dengan gambar yang dibuat.

Menggambar dapat menjadi kegiatan eksplorasi dan eksperimen sebagai pengalaman belajar anak dalam mengemukakan gagasan. Eksplorasi dan eksperimen terhadap ide, garis, warna, bentuk, media gambar dan hasil gambar menjadi sebuah karya kelompok. Anak mendapat kesempatan untuk mempresentasikan hasil karyanya sebagai sebuah pengalaman bekerjasama dan apresiasi sebuah karya.

Berikut dapat dikembangkan desain kegiatan menggambar berbasis proyek untuk anak usia dini dalam meningkatkan kemampuan sosial-emosional.

Tabel 1. Desain Kegiatan Proyek Menggambar

$\begin{array}{ll}\text { Tema } & \text { Negaraku } \\ \text { Sub tema } & \text { Kota dan Desa } \\ \text { Waktu } \quad: & 60 \text { menit } \\ \text { Proyek : Poster } & \\ \text { Alat dan bahan : krayon, pensil, kertas gambar }\end{array}$




\begin{tabular}{|c|c|c|}
\hline Materi & Aktivitas Anak & Aktivitas Guru \\
\hline $\begin{array}{l}\text { Slide/fil } \\
\text { m } \\
\text { Kehidupa } \\
\text { n kota } \\
\text { dan desa } \\
\end{array}$ & $\begin{array}{l}\text { Mengamati } \\
\text { slide/film } \\
\text { Kehidupan kota } \\
\text { dan desa }\end{array}$ & $\begin{array}{l}\text { Tanya jawab } \\
\text { slide/film }\end{array}$ \\
\hline $\begin{array}{l}\text { Alat dan } \\
\text { bahan }\end{array}$ & $\begin{array}{l}\text { - Anak } \\
\text { bereksperimen, } \\
\text { mengeksplorasi } \\
\text { dan } \\
\text { memanipulasi } \\
\text { alat dan bahan } \\
\text { menggambar }\end{array}$ & $\begin{array}{l}\text { - Menjelaskan } \\
\text { alat dan bahan } \\
\text { - Membagikan } \\
\text { alat dan bahan } \\
\text { tiap kelompok }\end{array}$ \\
\hline $\begin{array}{l}\text { Tahap- } \\
\text { tahap } \\
\text { kegiatan } \\
\text { proyek }\end{array}$ & $\begin{array}{l}\text { - } \text { Mempraktekka } \\
\text { n tahap-tahap } \\
\text { kegiatan }\end{array}$ & $\begin{array}{l}\text { - Menjelaskan } \\
\text { tahap-tahap } \\
\text { kegiatan }\end{array}$ \\
\hline $\begin{array}{l}\text { Lembar } \\
\text { Kerja }\end{array}$ & 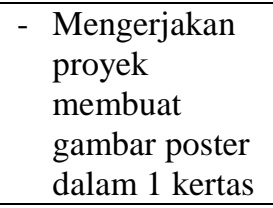 & $\begin{array}{l}\text { - Menjelaskan } \\
\text { cara } \\
\text { mengerjakan } \\
\text { lembar kerja }\end{array}$ \\
\hline $\begin{array}{l}\text { Diskusi } \\
\text { dan } \\
\text { Pengerja } \\
\text { an Tugas }\end{array}$ & $\begin{array}{l}\text { - } \text { Berdiskusi } \\
\text { untuk } \\
\text { pembagian } \\
\text { tugas dan } \\
\text { kesepakatan } \\
\text { tema poster } \\
\text { - } \text { Bekerjasama } \\
\text { dan } \\
\text { bertanggung } \\
\text { jawab dalam } \\
\text { kegiatan } \\
\text { kelompok } \\
\text { sesuai dengan } \\
\text { pembagian } \\
\text { tugas secara } \\
\text { indivisu } \\
\text { - Mengerjakan } \\
\text { gambar sesuai } \\
\text { dengan } \\
\text { kesepakatan } \\
\text { dalam } \\
\text { kelompok }\end{array}$ & $\begin{array}{l}\text { - Memotivasi, } \\
\text { memfasilitasi } \\
\text { dan memediasi } \\
\text { kegiatan diskusi } \\
\text { dan presentasi } \\
\text { anak dalam } \\
\text { kelompok }\end{array}$ \\
\hline $\begin{array}{l}\text { Presentas } \\
\mathrm{i}\end{array}$ & $\begin{array}{l}\text { - Mempresentasi } \\
\text { kan hasil } \\
\text { proyek } \\
\text { menggambar } \\
\text { poster }\end{array}$ & $\begin{array}{l}\text { - Memfasilitasi } \\
\text { presentasi setiap } \\
\text { kelompok }\end{array}$ \\
\hline
\end{tabular}

\section{METODE}

Rancangan penelitian ini menggunakan penelitian tindakan (action research) yang didefinisikan Mills (dalam (Mertler, 2011) sebagai penelitian sistematis apa saja yang dilaksanakan oleh para guru, penyelenggara pendidikan, guru konseling/penasihat pendidikan, atau lainnya yang menaruh minat dan berkepentingan dalam proses atau lingkungan belajar mengajar (PBM) dengan tujuan mengumpulkan informasi seputar cara kerja sekolah, cara mengajar guru, dan cara belajar siswa mereka.

Secara umum, proses penelitian tindakan versi (Mertler, 2011), berupa prosedur empat-tahap yakni sebagai berikut.

\section{Tahap Perencanaan}

Penelitian diawali dengan melakukan studi pendahuluan berupa observasi awal terhadap proses pembelajaran pengenalan sains anak usia dini pada tingkat satuan pendidikan TK. Observasi awal dilakukan untuk mengidentifikasi permasalahan yang dihadapi guru dalam mengembangkan kemampuan sosial-emosional anak dengan pendekatan dan kegiatan yang digunakan. Studi pendahuluan dilakukan dengan mengobservasi kegiatan menggambar di kelas. Berikutnya dilakukan diskusi dengan guru kelas berkaitan dengan pelaksanaan penelitian. Pada tahap ini, bersama dengan guru kelas menetapkan dan menyusun rancangan tindakan kegiatan menggambar berbasis proyek, yang meliputi : 1) Peta konsep, 2) Rencana Pelaksanaan Pembelajaran Mingguan (RPPM), 3) Rencana Pelaksanaan Pembelajaran Harian (RPPH), 4) Perangkat kegiatan menggambar berbasis proyek, dan 5) Instrumen penilaian kemampuan sosialemosional anak.

\section{Tahap Pengambilan Tindakan}

Setelah rencana awal disusun maka dilanjutkan dengan pelaksanaan kegiatan menggambar berbasis proyek sesuai dengan rencana yang telah dirancang sebelumnya.

\section{Tahap Pengembangan}

Tahap pengembangan meliputi proses pengamatan (observasi) dan evaluasi. (Madya, 2011) menyebutkan bahwa pelaksanaan observasi dilakukan terhadap: 1) proses tindakan, 2) pengaruh tindakan (baik sengaja maupun tidak disengaja), 3) keadaan dan kendala tindakan, 4) bagaimana keadaan dan kendala tersebut menghambat atau mempermudah tindakan yang telah direncanakan dan pengaruhnya, dan 5) persoalan lain yang timbul. Setelah mengetahui hasil pembelajaran pada tahap awal, dilakukan evaluasi rancangan dan 
pelaksanaan sehingga dapat dilakukan perbaikan dan pengembangan pada tahap selanjutnya.

4. Tahap Refleksi

Tahap refleksi yang dimaksud adalah mengingat dan merenungkan kembali suatu tindakan yang telah dicatat dalam proses observasi. Refleksi dilakukan untuk memahami proses, masalah persoalan, dan kendala yang nyata dalam tindakan strategik. Strategi memiliki aspek evaluatif, untuk menilai apakah pengaruh memang diinginkan, dan memberikan saran-saran tentang cara-cara untuk meneruskan tindakan. Disamping itu, refleksi juga bermakna deskriptif yaitu memungkinkan dilakukannya peninjauan, pengembangan gambaran yang lebih hidup tentang pembelajaran dan tindakan dalam situasinya, tentang kendala yang dihadapi dalam melakukan tindakan dan tentang apa yang sekarang mungkin dilakukan untuk mencapai tujuan.

Metode pengumpulan data yang digunakan dalam penelitian ini yakni melalui observasi. Proses pengumpulan data melalui teknik observasi ini menggunakan panduan rubrik untuk merekam data mengenai kemampuan sosial-emosional yang ditunjukan anak dalam kegiatan menggambar berbasis proyek. Menurut Mills, (dalam Kunandar 2012), Pengamatan dapat dilaksanakan dengan pedoman pengamatan (format, daftar cek), catatan lapangan, jurnal harian, aktivitas dikelas, penggambaran interaksi dalam, alat perekam elektronik atau pemetaan kelas. Proses pencatatan dapat dibantu dengan menggunakan instrumen.

Data peningkatan kemampuan sosialemosional anak dianalisis secara deskriptif, yaitu dengan melakukan observasi terhadap aktivitas yang dilakukan anak dengan bantuan instrumen penilaian. Keberhasilan anak dalam peningkatan kemampuan sosial-emosional dikatagorikan menjadi lima katagori yaitu sangat kurang, kurang, cukup, baik dan sangat baik. Cara menghitungnya adalah dengan mencari rata-rata, minimal memenuhi katagori baik. Aktivitas-aktivitas yang muncul selama proses pembelajaran sehubungan dengan implementasi tindakan dapat dihitung dengan pedoman observasi yang dilaksanakan. Tingkat kemampuan sosial emosional anak dapat ditentukan dengan membandingkan persentase penguasaan ke dalam konversi Penilaian Acuan Patokan (PAP) skala lima, yang tertera pada tabel 4.2 berikut.

Tabel 2. Pedoman Konversi Penilaian Acuan Patokan (PAP) Nasional

\begin{tabular}{|c|c|c|}
\hline $\begin{array}{c}\text { Persentase } \\
\text { Penguasaan }\end{array}$ & Katagori & Ketuntasan \\
\hline $90-100$ & Sangat tinggi & Tuntas \\
\hline $80-89$ & Tinggi & Tuntas \\
\hline $65-79$ & Sedang & Tuntas \\
\hline $55-64$ & Rendah & Belum Tuntas \\
\hline $00-54$ & Sangat rendah & Belum Tuntas \\
\hline \multicolumn{3}{|c}{ Sumber : Agung, 2014 }
\end{tabular}

Kriteria keberhasilan dalam penelitian ini adalah jika terjadi peningkatan kemampuan sosial emosional anak melalui kegiatan menggambar berbasis proyek. Indikator keberhasilan dalam penelitian ini apabila minimal $80 \%$ dari jumlah anak didik memenuhi kriteria sedang.

\section{HASIL DAN PEMBAHASAN}

Sebagai orientasi awal dilaksanakan observasi awal. Observasi awal dilaksanakan untuk mengetahui tingkat kemampuan sosial emosional anak usia dini pada saat mengikuti proses pembelajaran sebelum dilakukan tindakan. Hasil observasi awal kemampuan sosial emosional anak masih rendah. Persentase ketuntasan dicapai oleh 17 anak (68\%), dengan katagori sedang hingga sangat tinggi, delapan anak (32\%) masih berada dikategori rendah dan sangat rendah. Untuk itu perlu diberikan suatu tindak lanjut sebagai upaya perbaikan kemampuan sosial emosional anak.

\section{Hasil Penelitian}

Hal-hal yang dipersiapkan dalam siklus I ini meliputi Rencana Kegiatan Mingguan (RKM), Rencana Kegaiatan Harian (RKH), skenario pembelajaran, media pembelajaran, instrumen pemantauan kemampuan sosial emosional dan rubrik penilaian kemampuan sosial emosional. Rencana Kegiatan Mingguan (RKM), Rencana Kegaiatan Harian (RKH), dan 
skenario pembelajaran dirancang dan disusun sesuai dengan tema yang digunakan di PAUD Pelita Kasih Dalung. Siklus I direncanakan untuk 1 kali kegiatan proyek menggambar yaitu membuat poster tentang buah-buahan, masing-masing kegiatan dilaksanakan berdasarkan skenario pembelajaran. Proses penelitian menggunakan metode observasi pada setiap pertemuannya untuk menilai tingkat kemampuan sosial emosional anak.

Pelaksanaan tindakan siklus I dimulai pada bulan April minggu ketiga 2018. Siklus I dilaksanakan sesuai dengan skenario pembelajaran yang telah disiapkan.

Peningkatan kemampuan sosial emosional anak dilakukan melalui penerapan metode proyek dalam kegiatan menggambar. Hal ini ditunjukkan dari semakin meningkatnya jumlah ketuntasan kemampuan sosial emosional anak yakni sebanyak 19 anak (76\%), pada kategori sedang sampai sangat tinggi.

Hasil pemantauan seperti yang dipaparkan di atas menunjukkan bahwa secara umum kemampuan sosial emosional anak PAUD Pelita Kasih Dalung mengalami peningkatan. Ini ditunjukkan dari perubahan kemampuan sosial emosional anak pada saat observasi awal dengan saat pelaksanaan siklus I. Pada diagram berikut ditunjukkan Persentase penguasaan kemampuan sosial emosional pada observasi awal dan siklus 1 .

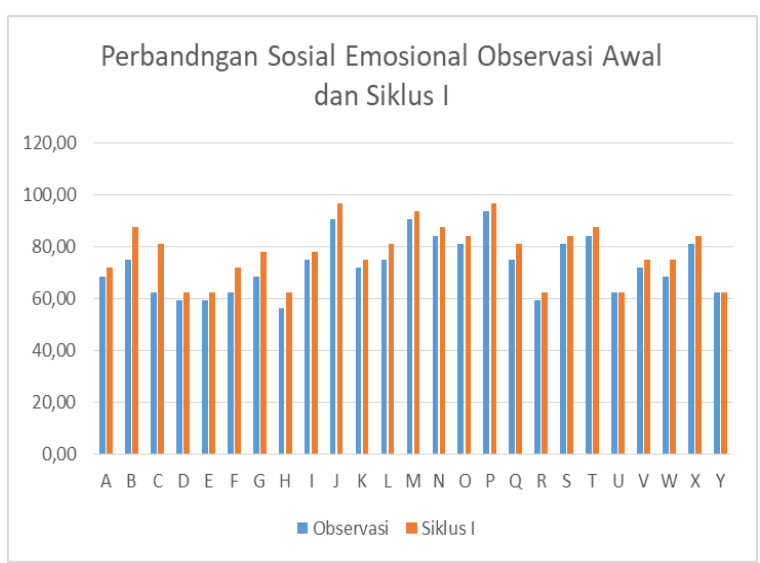

Gambar 2. Diagram Perbandingan

Persentase Kemampuan Sosial Emosional

Pada Observasi Awal dan Siklus 1
Pada Gambar 2 di atas, terlihat adanya peningkatan kemampuan sosial emosional anak usia dini. Pada saat observasi awal, 17 anak (68\%) yang mencapai ketuntasan. Setelah mengikuti kegiatan menggambar berbasis proyek terjadi peningkatan ketuntasan menjadi 19 anak $(76 \%)$ dengan rincian anak pada kategori sedang sebanyak 7 anak, 9 anak pada kategoti tinggi dan 3 anak pada kategori sangat tinggi.. Sedangkan 7 anak belum tuntas $(25 \%)$ masih pada kategori rendah sebanyak 6 anak. Berdasarkan hasil observasi pada siklus I diadakan refleksi dengan diskusi antara peneliti, guru dan kepala sekolah maka diidentifikasi kendala dan perbaikan yang memungkinkan dilakukan. Pelaksanaan siklus I dijumpai beberapa kendala diantaranya :

a. Beberapa anak belum memahami instruksi pelaksanaan proyek menggambar menyebabkan tidak terjadinya kesepahaman dalam kelompok untuk mengerjakan proyek menggambar

b. Kecenderungan anak meniru gambar/ide yang dibuat temannya sehingga poster yang dihasilkan merupakan pengulangan

c. Anak lebih menikmati aktivitas fisik dan observasi dibandingkan kegiatan diskusi dan mengekspresikan pikiran.

d. Beberapa anak pasif, sehingga didominasi anak-anak yang aktif dan ekspresif

e. Kurangnya partisipasi dan kemampuan anak dalam mempresentasi karya proyeknya

Sedangkan faktor pendukung dalam kegiatan menggambar berbasis proyek adalah sebagai berikut :

a. Menggambar merupakan kegiatan yang menyenangkan bagi anak sehingga anak antusias dalam melaksanakan proyek

b. Komunikasi dalam kelompok mudah terbentuk karena anak sudah saling mengenal akrab

c. Kegiatan menggambar menarik perhatian, antusias, dan partisipasi anak untuk melakukan kegiatan

d. Rasa ingin tahu yang besar pada anak

e. Kemampuan anak mengapresiasi karya temannya 
f. Partisipasi dan kerjasama peneliti, tim guru dan kepala sekolah

Berdasarkan kendala-kendala yang ditemui dan mengoptimalkan faktor-faktor pendukung pelaksanaan siklus I maka siklus II perlu dilaksanakan dengan pertimbangan persentase ketuntasan kemampuan sosial emosional anak belum mencapai $80 \%$ dan perlunya beberapa perbaikan kegiatan sehingga kendala yang ada di siklus I dapat teratasi dengan baik dan kemampuan sosial emosional anak pada siklus II dapat meningkat. Perbaikan yang dapat dilakukan pada siklus II adalah memberi motivasi dan apresiasi yang memadai kepada anak sehingga dapat menumbuhkan minat anak untuk berpartisipasi aktif dan bekerja sama dalam menghasilkan karya hasil proyek sebagai karya bersama. Hal ini sejalan dengan pernyataan (Kartono, 2007), bahwa anak merupakan pribadi sosial yang memerlukan relasi dan komunikasi dengan orang lain untuk memanusiakan dirinya. Anak ingin dicintai, ingin diakui dan dihargai.

Selanjutnya pada Siklus II, Hal-hal yang dipersiapkan dalam siklus II ini meliputi Rencana Kegiatan Mingguan (RKM), Rencana Kegaiatan Harian (RKH), skenario pembelajaran, media pembelajaran, instrumen pemantauan kemampuan sosial emosional dan rubrik penilaian kemampuan sosial emosional. Rencana Kegiatan Mingguan (RKM), Rencana Kegaiatan Harian (RKH), dan skenario pembelajaran dirancang dan disusun sesuai dengan tema yang digunakan di PAUD Pelita Kasih Dalung. Siklus II direncanakan untuk 1 kali kegiatan proyek menggambar yaitu membuat komik tentang binatang, masing-masing kegiatan dilaksanakan berdasarkan skenario pembelajaran. Proses penelitian menggunakan metode observasi pada setiap pertemuannya untuk menilai tingkat kemampuan sosial emosional anak.

Pelaksanaan tindakan siklus II dimulai pada bulan April minggu keempat 2018. Siklus II dilaksanakan sesuai dengan skenario pembelajaran yang telah disiapkan.
Peningkatan kemampuan sosial emosional anak dilakukan melalui penerapan metode proyek dalam kegiatan menggambar. Secara rinci nilai rata-rata kemampuan sosial emosional anak dalam kegiatan menggambar berbasis proyek pada siklus II. terjadi peningkatan kemampuan sosial emosional anak. Hal ini ditunjukkan dari semakin meningkatnya jumlah ketuntasan kemampuan sosial emosional anak yakni sebanyak 23 anak (92\%).

Hasil pemantauan dari kegiatan siklus II kemampuan sosial emosional anak dibandingkan dengan siklus I mengalami peningkatan yang signifikan sebagaimana ditunjukkan pada gambar 3 berikut ini.

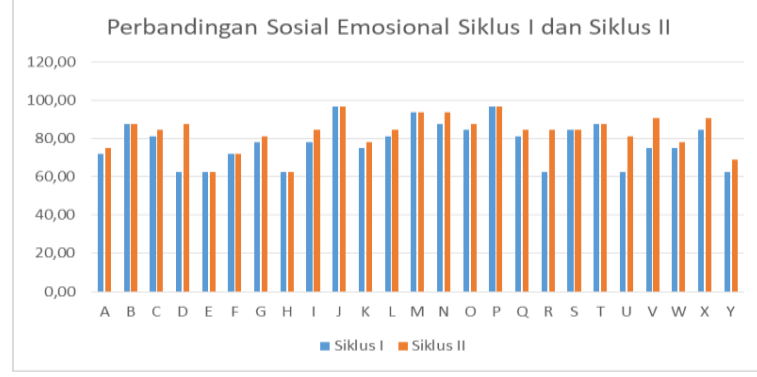

Gambar 3. Diagram Perbandingan

Persentase Kemampuan Sosial Emosional Anak Pada Siklus 1 dan Siklus II

Pada siklus II ketuntasan kemampuan sosial emosional anak telah mencapai $92 \%$ (meningkat 17\%) dari siklus I yaitu sebanyak 23 anak telah mencapai ketuntasan dengan kategori sedang (5 anak), tinggi (12 anak) dan sangat tinggi (6 anak), hanya menyisakan 2 anak dengan kategori rendah sehingga persentase penguasaan kemampuan sosial emosional yang belum tuntas (8\%). Dibandingkan dengan siklus I ada 1 anak dengan kategori rendah menjadi sedang, 3 anak dengan kategori rendah meningkat menjadi kategori tinggi, 2 anak dengan kategori sedang meningkat menjadi kategori tinggi, 1 anak dengan kategori sedang menjadi sangat tinggi, 2 anak dengan kategori tinggi meningkat menjadi kategori sangat tinggi, ada 14 anak berada pada kategori yang sama. Berdasarkan kategori tingkat kemampuan sosial emosional anak dapat dilihat perbandingannya dari observasi awal, siklus I dan siklus II, sebagaimana pada gambar berikut ini. 
Perbandingan Kategori Observasi Awal, Siklus I dan Siklus II

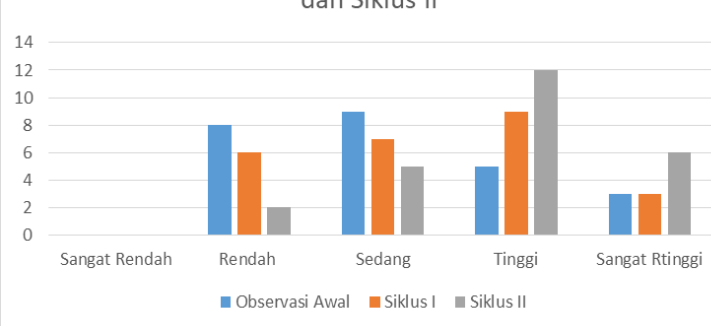

Gambar 4. Diagram Perbandingan Kategori

Tingkat Kemampuan Sosial Emosional Anak Pada Observasi Awal, Siklus 1 dan Siklus II

\section{PEMBAHASAN}

Hasil pra tindakan pada observasi awal, tindakan pada siklus I dan siklus II menunjukkan peningkatan kemampuan sosial emosional anak. Berikut dapat ditampilkan perbandingan dan peningkatan kemampuan sosial emosional masingmasing anak pada observasi awal, siklus I dan siklus II melalui Gambar 5.

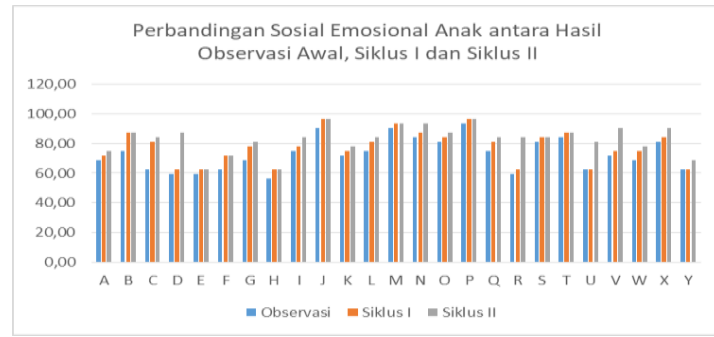

Gambar 5. Diagram Perbandingan Persentase Kemampuan Sosial Emosional Pada Observasi Awal, Siklus 1 dan Siklus II

Ditinjau dari rata-rata nilai indikator pada instrumen penelitian dari 9 indikator sosial emosional ditemui seluruhnya mengalami peningkatan dibandingkan observasi awal dan siklus I. Ada 5 Indikator kemampuan sosial emosional anak yang cukup besar mengalami peningkatan pada siklus II dibandingkan dengan siklus I, indikator itu adalah Mengenal perasaan sendiri dan mengelolanya secara wajar (mengendalikan diri secara wajar), Mengetahui perasaan temannya dan merespon secara wajar, Berbagi dengan orang lain, Menunjukkan sikap toleran, Mengekspresikan emosi yang sesuai dengan kondisi yang ada (senang-sedihantusias dan sebagainya).
Anak mengalami peningkatan kemampuan ini karena didukung oleh kegiatan proyek menggambar, dimana anak mendengar banyak informasi dan pengalaman belajar langsung melalui pengamatan, eksperimen, berkarya dan presentasi.

Kegiatan proyek menggambar memungkinkan anak banyak berinteraksi dengan teman sebaya, bekerjasama, mengerjakan lembar gambar, dan kesempatan mempresentasikan hasil kerjanya, sehingga kemampuan dalam mengekspresikan diri dengan teman sebaya berkembang. Hal ini sejalan pernyataan (Widayat, 2016) bahwa perkembangan emosi yang baik akan memungkinkan anak anak mengenali aspek-aspek emosi dirinya serta dapat mengekspresikannya secara tepat terhadap orang lain maupun lingkungan sekitarnya. Mengembangkan penguasaan kecakapan emosional dan kecakapan sosial penting bagi terbentuknya relasi yang positif dengan orang lain. Pemahaman emosi yang baik menjadi isyarat bagi perkembangan kesadaran diri yang positif yang akan mengarahkan anak untuk mencapai pembentukan jati dirinya seiring berjalannya waktu. Perbandingan rata-rata nilai tiap indikator dapat dijelaskan seperti pada gambar berikut.

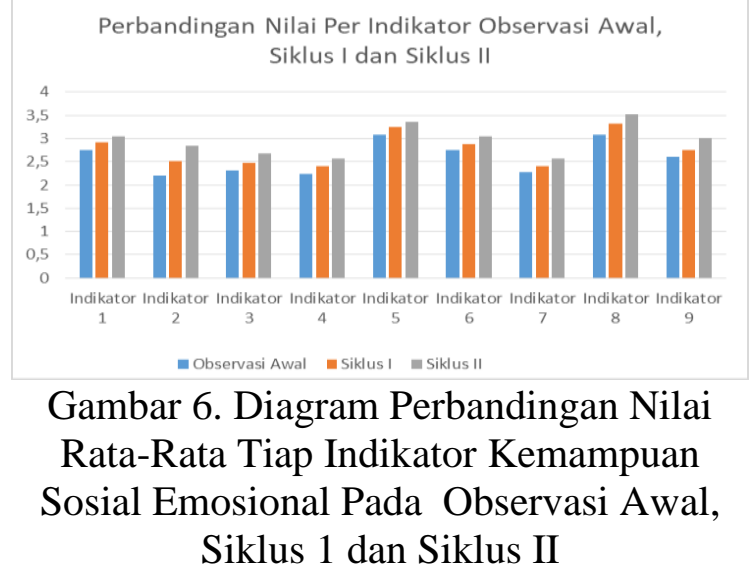

Peningkatan kemampuan sosial emosional anak pada siklus II dapat tercapai sebagai hasil upaya meminimalisir kendala yang ada, dan mengoptimalkan faktor-faktor yang mendukung, secara keseluruhan berdasarkan hasil pemantauan dan data observasi menunjukkan adanya peningkatan kemampuan berbahasa anak 
yang signifikan yaitu $92 \%$ anak telah mencapai kriteria ketuntasan dengan kategori sedang, tinggi dan sangat tinggi. Hal ini berarti bahwa penerapan kegiatan menggambar berbasis proyek mampu meningkatkan kemampuan sosial emosional anak.

Kegiatan menggambar berbasis proyek merupakan alternatif pembelajaran yang kreatif, karena dilakukan dengan mengoptimalkan daya imajinasi dan kemampuan bekerja sama anak melalui proyek menggambar yang merupakan pembelajaran dengan pengalaman langsung. Melalui kegiatan ini, anak akan mengembangkan kemampuan sosial emosional dengan cara menyenangkan dan bermakna, anak akan mampu mengkonstruksi pengetahuan dan pengalaman berinteraksi dengan alat dan bahan serta berkomunikasi dan berkolaborasi dengan teman sebaya melalui pengalaman kegiatan proyek menggambar. Hal ini sejalan dengan penelitian (Fauziddin, 2016) yang menyatakan bahwa pembelajaran atau kegiatan dengan kerja kelompok dapat melatih kerja sama anak yang meliputi berbagai unsur seperti kemampuan berinteraksi dengan teman kelompok, saling membantu dengan teman kelompok dan tanggung jawab dengan tugas kelompoknya Selain meningkatkan kemampuan sosial emosional anak, kegiatan menggambar berbasis proyek dapat menjadi kegiatan alternatif yang baik buat anak untuk mengalihkan dari bermain gadget yang membuat anak pasif dan tidak peduli dengan lingkungannya. Sebagaimana penelitian (Pebriana, 2017) yang menyatakan Gadget ternyata secara efektif dapat mempengaruhi pergaulan sosial anak terhadap lingkungan terdekatnya. Selain itu anak juga akan merasa asing dengan lingkungan sekitar karena kurangnya interaksi sosial selain itu anak juga kurang peka dan bahkan cenderung tidak perduli terhadap lingkungannya Berikut disajikan perbandingan ketuntasan anak dalam kemampuan sosial emosional pada observasi awal, siklus I dan siklus II.

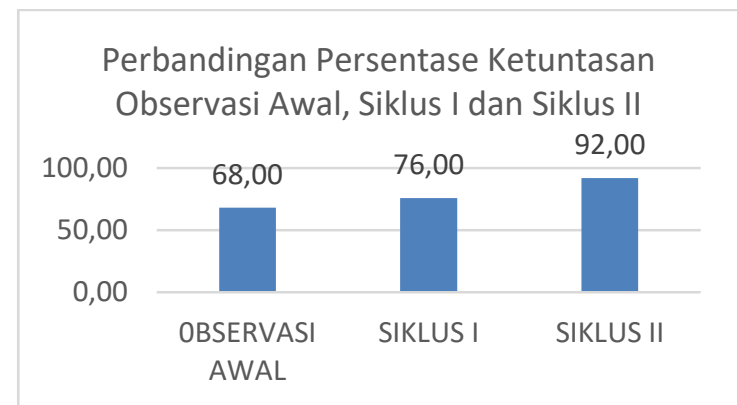

Gambar 7. Diagram Perbandingan

Ketuntasan Kemampuan Sosial Emosional Anak Pada Observasi Awal, Siklus 1 dan Siklus II

\section{SIMPULAN}

Kemampuan sosial emosional diperlukan anak dalam berinteraksi dengan lingkungan sekitarnya. Penelitian ini bertujuan untuk meningkatkan kemampuan sosial emosional anak melalui kegiatan menggambar berbasis proyek sehingga anak memiliki pengalaman bekerja dan berinteraksi dalam kelompok. Belajar mengemukakan pendapat, bertoleransi, mengungkapkan perasaan secara tepat, menghargai perbedaan, bermufakat, bertanggung jawab atas perilakunya, mengetahui haknya, serta mengenal aturan dan tata krama. Hasil penelitian yang dilaksanakan pada anak PAUD Pelita Kasih Dalung kelompok B semester 2 tahun pelajaran 2017/2018, menunjukkan kemampuan sosial emosional anak pada observasi awal Persentase ketuntasan dicapai oleh 17 anak (68\%), siklus I sebanyak 19 anak (76\%), dan siklus II 23 anak $(92 \%)$.

Kegiatan menggambar berbasis proyek mampu meningkatkan kemampuan sosial emosional anak Kelompok B PAUD Pelita Kasih, sehingga kegiatan ini dapat dijadikan sebagai alternatif dalam pengembangan aspek sosial emosional pada anak usia dini.

\section{UCAPAN TERIMA KASIH}

Terima kasih penulis ucapkan kepada semua pihak yang telah membantu dalam perencanaan dan pelaksanaan penelitian ini sehingga penulis dapat menyelesaikannya dengan baik dan lancar. Ucapan terima kasih ini khususnya ditujukan kepada : 
1. Kemenristek Dikti, selaku pemberi dana hibah penelitian dosen pemula

2. Dr.dr. Made Nyandra, SpKJ., M.Repro., FIAS., selaku Rektor Universitas Dhyana Pura, yang telah memberikan rekomendasi-rekomendasi guna kelancaran penyusunan penelitian.

3. Dr. Jaya Pramono, S,Pd., M.Par, selaku Dekan Fakultas Ekonomika dan Humaniora Universitas Dhyana Pura, yang telah banyak memberikan arahan dalam pelaksanaan penelitian ini.

4. Dr. Ni Made Diana Erfiani, S,S., M.Hum, selaku Ketua Lembaga Penelitian dan Pengabdian Masyarakat Universitas Dhyana Pura, yang telah banyak memberikan arahan dalam pelaksanaan penelitian ini.

5. Dra. Ni Kadek Suartini, M.Pd, selaku kepala PAUD Pelita Kasih Dalung yang telah memberikan ijin penulis untuk melaksanakan penelitian pada lembaga yang dipimpin, serta rekan guru PAUD Pelita Kasih Dalung

6. Reviewer dan editor Jurnal Obsesi yang memberi kesempatan artikel ini untuk diterbitkan

\section{DAFTAR PUSTAKA}

Cartledge, G., \& Kiarie, M. . (2011) 'Learning Social Skills Through Literature For Children And Adolescents. Teaching Exceptional Children', 34(2), p. 40-47.

Davido, R. (2012) La Decouverte de Votre Enfant Par le Dessin (Mengenal Anak Melalui Gambar. Jakarta: Penerbit Salemba Humanika.

Fauziddin, M. (2016) 'Peningkatan Kemampuan Kerja Sama melalui Kegiatan Kerja Kelompok Pada Anak Kelompok A TK Kartika Salo Kabupaten Kampar.', Jurnal Obsesi : Jurnal Pendidikan Anak Usia Dini, 2(1), pp. 29-45.

Geldard, K. \& D. G. (2012) Konseling Anak-Anak; Sebuah Pengantar Praktis. 3rd edn. Jakarta: PT. Indeks.

Günindi, Y. (2015) 'Preschool Children's Perceptions of the Value of Affection As Seen in Their Drawings',
International Electronic Journal of Elementary Education, 7(3), pp. 371382.

Hurlock, E. B. (2012) Psikologi Perkembangan: Suatu Pendekatan Sepanjang Rentang Kehidupan. 5th edn. Jakarta: Erlangga.

Kartono, K. (2007) Psikologi Anak (Psikologi Perkembangan). Bandung: Cv. Mandar Maju.

Kemendikbud (2014) Peraturan Kementerian Pendidikan dan Kebudayaan No. 146 Tentang Kurikulum 2013 Pendidikan Anak Usia Dini. Indonesia.

Lovitt, T. (2007) Preventing School Failure: Tactics For Teaching Adolescents. Austin: TX: Pro-Ed Publisher.

Madya, S. (2011) Penelitian Tindakan: Action Research; Teori dan Praktek. Bandung: Alfabet.

Mertler, C. A. (2011) Action Research, Mengembangkan Sekolah dan Memberdayakan Guru. Yogyakarta: Pustaka Pelajar.

Papalia, Diane E. Sally Wendkos Old, dan R. D. F. (2010) Human Development (Psikologi Perkembangan). 9th edn. Jakarta: Prenada Media Group.

Pebriana, P. (2017) 'Analisis Penggunaan Gadget terhadap Kemampuan Interaksi Sosial pada Anak Usia Dini', urnal Obsesi: Jurnal Pendidikan Anak Usia Dini, 1(1), pp. $1-11$.

Rachmawati, Y. dan E. K. (2010) Strategi Pengembangan Kreativitas Anak Usia Taman Kanak-Kanak. Jakarta: Kencana Prenada Media Group.

Soetjiningsih, C. H. (2012) Perkembangan Anak, Sejak Pembuahan Sampai dengan Kanak-Kanak Akhir. Jakarta: Prenada Media Group.

Widayat, I. W. (2016) Psikologi Perkembangan \& Pendidikan Anak Usia Dini. Sebuah Bunga Rampai. Jakarta: Prenada Media Group. 